\title{
PENERAPAN PEMBERIAN TUGAS INDIVIDU DALAM KERJA KELOMPOK UNTUK MENINGKATKAN PRESTASI BELAJAR PKN SISWA KELAS V SEMESTER I SD NEGERI 12 PEGUYANGAN TAHUN PELAJARAN 2013/2014
}

\author{
Ni Nyoman Darmini \\ SD Negeri 12 Peguyangan \\ Email: ninyomandarmini2018@gmail.com
}

\begin{abstract}
ABSTRAK
Tujuan penulisan penelitian tindakan kelas ini adalah untuk mengetahui apakah pemberian tugas individu dalam kerja kelompok dapat meningkatkan prestasi belajar siswa SD negeri 12 Peguyangan di Kelas V semester I tahun pelajaran 2013/2014. Data dalam penelitian ini dikumpulkan dengan tes prestasi belajar. Metode analisis datanya adalah deskriptif. Hasil yang diperoleh dari penelitian ini penggambaran secara lengkap dapat dijabarkan sebagai berikut: hasil yang diperoleh pada awalnya 51,42 dengan prosentase ketuntasan 40,47\%, pada siklus I menjadi 69,76 dengan prosentase ketuntasan $64,28 \%$ dan pada siklus II menjadi 82,14 dengan prosentase ketuntasan $100 \%$. Hasil tersebut setelah dilakukan analisis menggunakan analisis deskriptif diperoleh kesimpulan bahwa pemberian tugas individu dalam kerja kelompok dapat meningkatkan prestasi belajar PKN siswa kelas V semester I SD Negeri 12 Peguyangan Tahun Pelajaran 2013/2014.
\end{abstract}

Kata Kunci: Pemberian Tugas Individu Dalam Kerja Kelompok, Prestasi Belajar

\section{ABSTRACT}

The purpose of this class action research writing is to find out whether giving individual tasks in group work can improve the learning achievement of 12 Peguyangan elementary school students in Class $V$ in the first semester of the 2013/2014 academic year. Data in this study were collected with learning achievement tests. The data analysis method is descriptive. The results obtained from this research complete description can be described as follows: the results obtained initially 51.42 with a percentage of completeness $40.47 \%$, in the first cycle to 69.76 with a percentage of completeness $64.28 \%$ and in the second cycle to 82,14 with a percentage of 100\% completeness. These results after analyzing using descriptive analysis concluded that giving individual assignments in group work can improve PKN learning achievement of fifth grade students of the first semester of Peguyangan 12 State Elementary School 2013/2014 Academic Year.

Keywords: Individual Assignment Work Group, Learning Achievement

\section{PENDAHULUAN}

Guru memiliki peran dalam upaya menciptakan proses pembelajaran yang efektif dan berkualitas. Kemampuan dan kreatifitas guru dalam merancang dan mengelolah pembelajaran sangat dituntut, sehingga menciptakan pembelajaran yang menarik dan akan berdampak pada pencapaian kompetensi siswa secara menyeluruh. Kompetensi siswa akan berkembang secara optimal tergantung bagaimana guru memposisikan diri dan menempatkan siswa dalam pembelajaran.

Sejalan dengan arah perubahan paradigma pembelajaran, guru hendaknya menempatkan siswa sebagai pelaku 
utama (subyek) dalam proses pembelajaran, sementara guru lebih memposisikan diri sebagai fasilitator, motivator, dan mediator. Melalui proses tersebut, diharapkan pembelajaran yang terjadi dapat mengaktifkan siswa secara maksimal dalam penelusuran segala informasi yang dibutuhkan hingga pada proses penemuan dan penyusunan (konstruksi) pengetahuan secara aktif oleh siswa. Untuk itu, pemilihan pendekatan, model, strategi maupun metode yang tepat dalam pembelajaran mutlak untuk dipahami dan dimiliki oleh guru.

Kenyataan di lapangan menunjukkan bahwa secara umum masih banyak guru yang menggunakan proses pembelajaran yang tidak memotivasi dalam belajar, bahkan tidak mengupayakan pada pengembangan kemampuan siswa secara menyeluruh pada aspek kognitif, afektif dan psikomotor. Kondisi tersebut sangat erat kaitannya dengan pendekatan, model maupun metode pembelajaran yang digunakan. Umunya guru masih menggunakan pola pembelajaran konvesional, dimana pembelajaran yang dilakukan cenderung didominasi oleh aktifitas ceramah, tanya jawab, dan pemberian tugas. Proses pembelajaran dengan cara tersebut memang memiliki keunggulan pada beberapa pokok bahasan untuk mata pelajaran PKn, namun apabila dilakukan secara terus menerus akan menyebabkan siswa kurang termotivasi dan akan melahirkan kejenuhan siswa dalam mengikuti proses pembelajaran Proses pembelajaran sebagaimana dipaparkan sebelumnya, ditemukan pula pada pembelajaran mata pelajaran PKn di SD Negeri 12 Peguyangan. Observasi awal yang dilakukan pada SD Negeri 12 Peguyangan, khususnya pada kelas $\mathrm{V}$, ditemukan bahwa proses pembelajaran yang dilakukan masih mengacu pada paradigma lama, yaitu menempatkan guru sebagai subyek belajar dan siswa menjadi obyek belajar. Metode pembelajaran yang digunakan cenderung masih sangat konvensional, yaitu pembelajaran yang didominasi oleh metode ceramah. Aktifitas siswa dalam pembelajaran sangat pasif, dimana siswa hanya terbatas pada kegiatan mendengarkan penjelasan guru dan juga mencatat beberapa informasi yang dianggap penting.

Hasil observasi dan wawancara awal ditemukan pula, bahwa dalam proses pembelajaran guru hanya meminta siswa mencatat kembali materi pelajaran yang terdapat pada buku teks yang digunakan oleh guru. Hal tersebut dilakukan oleh guru karena terbatasnya buku paket yang dimiliki oleh sekolah maupun yang dimiliki oleh siswa. Diakui, bahwa teknik maupun metode-metode tersebut cukup efektif dalam upaya guru menyelesaikan materi yang dipelajari, namun sangat tidak efektif dalam upaya pencapaian tujuan pembelajaran yang telah ditetapkan. Tidak tercapainya tujuan pembelajaran tersebut, dapat dilihat pada hasil evaluasi semester ganjil tahun pelajaran 2013/2014.

Hasil evaluasi semester ganjil mata pelajaran PKn siswa kelas IV SD Negeri 12 Peguyangan, menunjukkan bahwa ketuntasan belajar klasikal (KBK) sangat tidak memenuhi standar KBK yang ditetapkan, yaitu $\geq 80 \%$. Dari hasil analisis tes evaluasi semester ganjil tersebut, diperoleh $\mathrm{KBK}$ siswa hanya mencapai $40 \%$ dan selebihnya, yaitu sebesar $60 \%$ harus mengikuti remedial.

Hal tersebut menunjukkan bahwa dari 20 jumlah siswa kelas $\mathrm{V}$ pada tahun pelajaran 2013/2014, hanya 8 orang yang mencapai nilai kriteria ketuntasan minimal 
yang ditetapkan, yaitu $\geq 65$. Kondisi tersebut membutuhkan upaya perbaikan, yaitu dengan menerapkan metode pembelajaran yang diharapkan dapat membangkitkan motivasi belajar siswa, sehingga siswa dapat melakukan proses belajar secara aktif. Salah satu metode pembelajaran yang dapat digunakan adalah metode pemberian tugas. Sardiman (2008:90) menjelaskan bahwa metode pemberian tugas merupakan alat motivasi yang baik, dengan pemberian tugas siswa akan diberi tanggung jawab untuk menyelesaikan tugasnya, sehingga siswa akan melakukan proses belajar.

Melalui pemberian tugas kepada siswa, diharapkan siswa dapat melakukan proses belajar untuk menyelesaikan tugasnya serta mempertanggung jawabkan tugasnya tersebut. Dengan demikian, siswa dapat melakukan aktifitas belajar dengan adanya tugas yang diberikan. Disamping itu, dengan mengerjakan tugas siswa akan melatih kemampuan berpikirnya dalam upaya menyelesaikan soal-soal atau tugastugas yang diberikan. Salah bentuk pemberian tugas adalah pemberian tugas rumah. Tugas rumah merupakan bentuk tugas yang diberikan kepada siswa yang penyelesaiannya dilakukan siswa di rumah. Melalui tugas rumah diharapkan orang tua memiliki peran dalam membantu siswa (anaknya) menyelesaikan tugasnya dengan memberikan bimbingan ataupun melakukan pendampingan kepada anaknya.

Pemberian metode pemberian tugas terbukti berpengaruh positif terhadap hasil belajar siswa. Hasil penelitian yang dilakukan oleh Suwasto (2012: 249) menyimpulkan bahwa metode penugasan dapat membantu siswa untuk lebih bisa memahami dan menghayati mata pelajaran $\mathrm{PKn}$, dan dapat mengukur mengukur kemampuan siswa dari ranah kognitif dan afektifnya.

Berdasarkan latar belakang masalah tersebut, peneliti tertarik untuk melakukan penelitian tentang penggunaan metode pemberian tugas terhadap peningakatan hasil belajar PKn dengan judul penelitian "Penerapan Pemberian Tugas Individu Dalam Kerja Kelompok Untuk Meningkatkan Prestasi Belajar Pkn Siswa Kelas V Semester I SD Negeri 12 Peguyangan Tahun Pelajaran 2013/2014". Rumuan masalah penelitian ini adalah apakah hasil belajar siswa kelas V SD Negeri 12 Peguyangan pada mata pelajaran PKn dapat ditingkatkan melalui penggunaan metode pemberian tugas kelompok. Adapun tujuan penelitian ini adalah "untuk meningkatkan hasil belajar siswa kelas V SD Negeri 12 Peguyangan pada mata pelajaran PKn melalui penggunaan metode pemberian tugas kelompok.

\section{METODE PENELITIAN}

Penelitian ini merupakan penelitian tindakan kelas (PTK) yang dilakukan secara bersiklus dalam 2 (dua) siklus. Desain PTK yang digunakan adalah model spiral Kemmis dan Mc Taggart yang terdiri dari 4 (empat) tahap, yaitu: 1) perencanaan (planning), 2) pelaksanaan (acting), 3) pengamatan (observing), dan 4) refleksi (reflecting) (Asikin, dkk., 2009: 42). PTK ini dilakukan di kelas V SD Negeri 12 Peguyangan, subjek sebanyak 20 orang siswa. Peneliti dalam penelitian ini merupakan guru kelas dan dalam pelaksanaan proses penelitian dibantu oleh 2 (dua) orang partisipan yang bertindak sebagai observer.

Teknik pengumpulan data dalam penelitian ini adalah dengan menggunakan tes dan pengamatan/observasi. Tes evaluasi 
hasil belajar yang diberikan pada setiap akhir setiap siklus menggunakan tes bentuk pilihan ganda sebanyak 20 butir soal setiap pelaksanaan tes. Pengamatan dilakukan terhadap keterlaksanaan proses pembelajaran melalui aktivitas siswa dan guru dalam proses pembelajaran baik pada siklus I maupun siklus II. Analisis data tes hasil belajar dilakukan dengan melakukan analisis pada aspek daya serap klasikal (DSK) dan ketuntasan belajar klasikal (KBK). Analisis data hasil pengamatan aktifitas guru dan siswa dilakukan secara deskriptif, yaitu dengan menginterperstasikan hasil pengamatan terhadap nilai-nilai yaitu sangat kurang (0 20), kurang (21 - 40), cukup (41 - 60), baik $(61-80)$, dan sangat baik $(81-100)$. Indikator keberhasilan PTK ini yaitu jika daya serap individu mencapai $65 \%$ dan ketuntasan belajar klasikal mencapai $85 \%$ dan rata-rata persentase aktifitas guru, kemampuan psikomotor serta afektif berada pada kategori baik.

\section{HASIL PENELITIAN DAN PEMBAHASAN \\ Hasil Penelitian}

Hasil tes evaluasi akhir siklus I diperoleh skor nilai terendah adalah 60 (6 orang) dan skor tertinggi 80 (2 orang). Jumlah siswa yang tuntas 14 orang dan yang tidak tuntas 6 orang dari 20 orang subyek penelitian. Persentase KBK diperoleh :

70.0\%. Tes evaluasi akhir siklus II, diperoleh skor terendah adalah 60 (1 orang) dan skor tertinggi adalah 80 (9 orang). Jumlah siswa yang tuntas 19 orang dan yang tidak tuntas 1 orang. Persentase DSK.075\% dan KBK 95.0\%. Deskripsi data hasil tes evaluasi akhir siklus I dan siklus II disajikan pada Tabel 1.

Tabel 1. Deskripsi Data Tes Evaluasi Akhir Siklus I dan Siklus II

\begin{tabular}{lcc}
\hline \multirow{2}{*}{ Aspek Perolehan } & \multicolumn{2}{c}{ Hasil } \\
\cline { 2 - 3 } & Siklus I & Siklus II \\
\hline Jumlah Siswa & 20 orang & 20 orang \\
\hline Skor Terendah & $60(6$ orang $)$ & $60(1$ orang $)$ \\
\hline Skor Tertinggi & $80(2$ orang $)$ & $80(9$ orang $)$ \\
\hline Jumlah Siswa yang Tuntas & 14 orang & 19 orang \\
\hline Ketuntasan Belajar Klasikal & $70 \%$ & $95 \%$ \\
\hline
\end{tabular}

Hasil pengamatan aktifitas guru dan siswa pada siklus I, diperoleh persentase aktifitas guru rata-rata $58.9 \% \%$ dengan kategori cukup, aktifitas siswa rata-rata $69.5 \%$ kategori baik. Hasil pengamatan pada siklus II, diperoleh rata-rata aktifitas guru maupun aktifitas siswa berada pada kategori sangat baik. Persentase rata-rata aktifitas guru adalah $85.7 \%$ kategori sangat baik, dan aktifitas siswa sebesar $88.7 \%$ kategori sangat baik. Hasil analisis data pengamatan aktifitas guru dan siswa disajikan pada Tabel 2.

Tabel 2. Deskripsi Data Hasil Pengamatan Aktifitas Guru dan Siswa

\begin{tabular}{cccccc}
\hline \multirow{2}{*}{ No. } & \multirow{2}{*}{ Aspek Pengamatan } & \multicolumn{2}{c}{ Siklus I } & \multicolumn{2}{c}{ Siklus II } \\
\cline { 3 - 6 } & & $\mathbf{\%}$ & Kategori & $\boldsymbol{\%}$ & Kategori \\
\hline 1 & Aktifitas Guru & 58.9 & Cukup & 85.7 & Sangat Baik \\
\hline 2 & Aktifitas Siswa: & 69.5 & Baik & 88.7 & Sangat Baik \\
\hline
\end{tabular}




\section{Pembahasan}

Hasil observasi aktifitas guru pada pembelajaran siklus I tergolong dalam kategori cukup, sedangkan hasil observasi pada siklus II mengalami peningkatan dari dengan kategori sangat baik. Berdasarkan kategori aktifitas yang dilakukan oleh guru dalam pembelajaran siklus I, secara umum keseluruhan aspek yang diobservasi perlu diperbaiki. Penyampaian materi pelajaran, pemberian kesempatan kepada siswa untuk bertanya hal-hal yang belum dimengerti, memberikan penguatan kepada siswa yang bertanya atau menjawab dengan benar dan mengarahkan siswa dalam mengerjakan tugas evaluasi khususnya tugas rumah, merupakan hal-hal pokok yang perlu diperbaiki oleh guru. Membimbing siswa dalam presentase hasil kerja kelompok agar memperoleh hasil yang lebih baik lagi sehingga dapat mencapai taraf keberhasilan yang lebih tinggi.

Aktifitas siswa dalam kegiatan belajar mengajar pada siklus I berada pada kategori baik. Hal tersebut mengalami peningkatan pada siklus II termasuk dalam kategori sangat baik. Hal ini menunjukkan adanya upaya perbaikan berdasarkan refleksi pada siklus I. Perbaikan-perbaikan tersebut antara lain kesiapan siswa dalam mengikuti proses pembelajaran, keaktifan siswa dalam berdiskusi, dan efektifitas siswa dalam mengerjakan tugas yang diberikan, sudah mencapai kategori baik. Peningkatan yang terjadi ini menunjukkan bahwa guru telah meningkatkan kinerjanya dalam memperbaiki kekurangan-kekurangan yang terjadi pada siklus I. Peningkatan aktifitas guru dan siswa dari siklus I ke siklus II menyebabkan pula peningkatan hasil belajar siswa. Peningkatan hasil belajar dalam penelitian ini dapat dilihat dari data yang telah diolah yang menunjukkan pada evaluasi akhir pada siklus I diperoleh 14 orang siswa yang tuntas secara individu dan 6 orang siswa yang tidak tuntas dengan nilai
$60 \%$ serta daya serap klasikal yaitu $\quad 68.5 \%$ sedangkan presentase ketuntasan belajar klasikal mencapai $70.00 \%$. Hal ini menunjukkan bahwa hasil tes evaluasi pada siklus I belum memenuhi standar ketuntasan keberhasilan yang ditetapkan, berdasarkan indikator keberhasilan suatu kelas dikatakan tuntas jika mencapai daya serap individual $65 \%$ dan ketuntasan belajar klasikal mencapai 85\% (Depdiknas, 2001).

Ada beberapa hal yang menyebabkan banyak siswa yang tidak tuntas yaitu karena siswa tidak memperhatikan tujuan pembelajaran yang disampaikan oleh guru, siswa tidak dengan sungguh-sungguh memperhatikan penjelasan dan petunjuk yang diberikan oleh guru, siswa kurang aktif dalam berdiskusi dan bersifat pasif dalam mencari jawaban soal yang ada dalam LKS. Kondisi tersebut disebabkan salah satunya karena siswa belum terbiasa dengan pembelajaran dengan metode bervariasi seperti metode pemberian tugas secara terencana dengan baik yang diterapkan sehingga belum percaya diri untuk mengeluarkan pendapat. Berdasarkan hasil tersebut, maka perlu dilakukan perbaikan dalam pelaksanaan pembelajaran pada siklus II berdasarkan hasil refleksi siklus I meliputi kegiatan memotivasi siswa, penyampaian materi yang lebih jelas dan pembimbingan siswa dalam proses pembelajaran. Perbaikan tersebut dilakukan dalam upaya meningkatkan hasil belajar siswa yaitu dengan mengadakan pendekatan dan memberikan pemahaman bahwa belajar dengan sungguh-sungguh dan saling berdiskusi serta kerja sama akan lebih mempermudah dalam memahami pelajaran.

Pada siklus II menunjukkan peningkatan hasil belajar siswa dibandingkan dengan siklus I. Hal tersebut dapat dilihat dari hasil tes evaluasi akhir pada siklus II siswa yang tuntas secara individu sebanyak 20 siswa atau semua siswa tuntas dalam belajar. 
Hasil analisis data menunjukkan bahwa daya serap klasikal $75.0 \%$ dan ketuntasan belajar klasikal mencapai 95\%. Hal ini menunjukkan bahwa kegiatan tindakan pembelajaran siklus II telah mencapai standar ketuntasan keberhasilan yang ditetapkan. Ketercapaian ketuntasan belajar pada siklus II ini membuktikan bahwa pelaksanaan tindakan dengan menggunakan metode pembelajaran pemberian tugas dalam pembelajaran PKn dapat meningkatkan hasil belajar siswa, sehingga penelitian ini berakhir pada siklus II. Hasil penelitian ini, sejalan dengan pendapat yang dikemukakan Dimyati dan Moedjiono (2002) bahwa hasil belajar merupakan hasil dari suatu interaksi tindak mengajar atau tindak belajar. Hasil belajar mempunyai peranan penting dalam proses pembelajaran. Proses penilaian terhadap hasil belajar dapat memberikan informasi kepada guru tentang kemajuan siswa dalam upaya mencapai tujuan-tujuan belajarnya melalui kegiatan belajar.

Metode pembelajaran pemberian tugas dalam pembelajaran PKn pada siswa kelas V SD Negeri 12 Peguyangan juga dapat meningkatkan keaktifan siswa dalam mencari dan mengungkapkan jawaban terhadap pertanyaan (tugas) yang diberikan. Selain itu dapat meningkatkan kerja sama dalam proses belajar mengajar, serta memberikan kebebasan kepada siswa dalam bertanya atau berdiskusi dengan teman-teman kelompok. Siswa juga lebih paham jika teman-teman yang mengajari karena mereka merasa bebas bertanya apa yang belum jelas. Pemberian tugas yang dilakukan dengan mengacu pada karakteristik siswa dan hal-hal yang dapat ditemukan siswa dalam kehidupan sehari-hari, menyebabkan siswa lebih mudah dalam memahami dan menerima materi yang diajarkan.

Hal tersebut sejalan dengan pendapat yang dikemukakan oleh Roestiyah (2008:134) yang menyatakan bahwa melalui metode pemberian tugas memberikan keuntungan antara lain 1) dapat membangkitkan siswa untuk lebih giat belajar, apalagi tugas yang diberikan sesuai dengan kebutuhan siswa, 2) dapat memupuk rasa tanggung jawab siswa, 3) dapat memupuk rasa percaya diri sendiri, dan 4) dapat mengembangkan pola berpikir, keterampilan, efektif siswa yang berhubungan dengan tugas yang diberikan kepadanya. Hasi penelitian ini memperkuat beberapa hasil penelitian sebelumnya, diantaranya Suwasto (2012) yang meneliti tentang peningkatan hasil belajar PKn materi konsep nilai-nilai Pancasila sebagai dasar negara dan ideologi melalui metode diskusi dan resitasi.

\section{PENUTUP}

Kesimpulan dari penelitian ini adalah bahwa Hasil belajar siswa pada Pelajaran PKn siswa kelas V SD Negeri 12 Peguyangan dapat ditingkatkan melalui penerapan metode pemberian tugas.Saran rekomendasi dari hasil penelitian ini adalah diharapkan dalam pembelajaran bidang studi PKn di sekolah dasar (SD) agar menerapkan metode pembelajaran bervariasi seperti metode pemberian tuags untuk mengingkatkan hasil belajar siswa.

\section{DAFTAR PUSTAKA}

Depdiknas. (2001). Undang-undang Nomor 20 Tahun 2003 Tentang Sistem Pendidikan Nasional. Jakarta: Departemen Pendidikan Nasional.

Dimyati dan Mudjiono. (2002). Belajar dan Pembelajaran. Jakarta: Rineka Cipta.

Roestiyah, N. K. (2008). Strategi Belajar Mengajar. Jakarta: Rineka Cipta

Sardiman, A. M. (2008). Interaksi dan Motivasi Belajar Mengajar. Jakarta: PT. Raja Grafindo Persada.

Susilo, H., Chotimah, H. dan Sari, Yuyun D. 2009. Penelitian Tindakan Kelas sebagai Sarana Pengembangan Keprofesionalan Guru dan Calon Guru. Malang: Bayumedia Publishing. 
Suwasto. (2012). Peningkatan Hasil Belajar PKn Materi Konsep Nilai-nilai Pancasila sebagai Dasar Negara dan Ideologi melalui Metode Diskusi dan Resitasi. Dinamika. 3(2): 245 - 249. 